\title{
New Faunistic Records of Armoured Scale Insects of Southern Iran (Hemiptera: Diaspididae)
}

\author{
Mohammad Rouhani ${ }^{*}$, Hassan Ali Vahedi ${ }^{1}$, Alireza Marefat ${ }^{1}$ \\ ${ }^{I}$ Department of Plant Protection, Campus of Agriculture and Natural Resources, Razi University, Kermanshah, Iran
}

\begin{abstract}
As a result of recent field work in southern Iran from 2012 to 2016, twenty species of armoured scale insects were collected, representing two subfamilies (Aspidiotinae and Diaspidinae) and 4 tribes including Aspidiotini ( 8 species in 5 genera), Diaspidini (4 species in 2 genera), Leucaspidini (5 species in 4 genera) and Parlatoriini (3 species in 1 genus). The species Diaspidiotus gigas (Thiem and Gerneck), is illustrated and redescribed from Iran for the first time. In addition, four species are reported and redescribed from south of Iran for the first time: Aspidiotus nerii Bouché, Diaspidiotus armenicus Borchsenius, Leucaspis pusilla Löw, Melanaspis louristana Balachowsky and Kaussari.
\end{abstract}

Key words: Diaspididae, Coccomorpha, tribes, Iran, new record

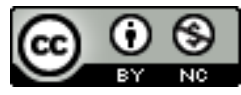

*Author for correspondence: Rouhani_valiasr@yahoo.com; Rouhanientomo@gmail.com 


\section{INTRODUCTION}

The armoured scale insects (Diaspididae) belong to a family of animals in the insect superfamily Coccoidea (Order Hemiptera). It is the largest family of scale insects, containing nearly 2595 species in about 418 genera. So far, 151 armoured scale species have been recorded from Iran, in 44 genera ${ }^{1,2}$. They are plant sap-sucking insects and many species are extremely polyphagous pests (e.g. Aspidiotus nerii (Bouché) with 325 hosts belonging to 120 plant families). The Diaspdidae are generally considered to be one of the most economically important, destructive groups of pests on agricultural and horticultural crops ${ }^{3-6}$.

Iranian scale insects have been studied by several coccidiologists. Some literature on the Diaspididae of Iran includes: Archangelskaya (1937), Afchar (1937), Borchsenius (1952), Balachowsky (1959); Balachowsky (1967), Kaussari (1957), Kaussari (1970), Seghatoleslami (1977), Torabi et al. (2010), Rozdar et al. (2013) and Hosseininaveh et al. (2016) ${ }^{7-17}$.

Armoured scale insects are very small, the adult female usually being 1-3 mm long. They are fairly easy to recognize because of their many unusual adaptations. The body of the female insect is protected by a hardened, waxy scale cover that is not attached to the body; it can be exposed by lifting off this armoured. The exposed body is usually yellow or orange but may be pink or red, depending on the species and the age of the insect. The scale cover varies from circular to elongate or oyster shell-shaped and contains $1^{\text {st }}$ and usually the $2^{\text {nd }}$ instar exuviae, which are incorporated and usually visible ${ }^{18}$. Male and female scale covers usually differ in size and shape in the same species; the female cover is generally the largest ${ }^{18}$.

Armoured scales occur on almost any part of the plant (aerial and underground parts): e.g. Lepidosaphes pistaciae Archangelskaya on the leaves and bark of Pistacia vera L. (Sapindales: Anacardiaceae) ${ }^{4-5}$; hypogeic diaspidids occur on roots, e.g. Chortimaspis salavatiani on the rhizomes of Agropyron repens ${ }^{15}$. Some diaspidid species show preference for tight, protected areas, such as the cracks and crevices of bark, or leaf axils. So far, no comprehensive investigation of coccids has been undertaken in the Kerman region (southern Iran). The purpose of this study is to update knowledge of the armoured scale insect fauna occurring on trees, and to determine the taxonomic status and some diagnostic morphological characteristics of the species new to this region.

\section{MATERIALS AND METHODS}

A field survey of armoured scale insects was carried out in southern Iran (South-West Kerman Province) between 2012 and 2016, by visual inspection of various potentially infested plant species using a 10x magnification lens. Infested host-plant parts including stems, branches and leaves were collected on irregular surveys in different areas. Each sample was labelled with the collection data. In the laboratory, adult females were removed from infested plant parts and were preserved in $75 \%$ alcohol. A number of specimens were mounted on microscope slides using the methodology of Hodgson and Henderson ${ }^{12}$ and identified using Kaussari (1957), Kaussari (1970), Danzig (1993) Gill (1997), Moghaddam (1998), Watson (2002a) and Watson (2002b) ${ }^{4,5,13,14,20-22}$. The slides are stored in the Plant Protection Department collection at Razi University. All measurements are given in micrometers $(\mu \mathrm{m})$. Images and measurements were taken with a Leitz compound microscope using a drawing tube. 


\section{RESULTS}

A total of 20 diaspidid species belonging to 4 tribes and 12 genera (Table 1) were collected on cultivated and non-cultivated plants. Among these species, Diaspidiotus gigas Thiem and Gerneck 1934 is reported for the first time from Iran (Kerman, south Iran), and redescribed and illustrated below; also Aspidiotus nerii Bouché 1833, Diaspidiotus armenicus Borchsenius 1935, Leucaspis pusilla Löw 1883 and Melanaspis louristana Balachowsky and Kaussari 1953 are reported from the study area in southern Iran for the first time.

Table 1 - Armoured scale insect species found in the Kerman region, southern Iran.

\begin{tabular}{|c|c|c|c|c|}
\hline Species & Subfamily & Tribe & Host plants & Locality GPS \\
\hline $\begin{array}{c}\text { Aspidaspis dentilobus } \\
\text { Kaussari and Balachowsky, } \\
1953\end{array}$ & Aspidiotinae & Aspidiotini & Atraphaxis spinosa & Kerman \\
\hline $\begin{array}{c}\text { Aspidiotus nerii Bouché, } \\
1833\end{array}$ & Aspidiotinae & Aspidiotini & Nerium oleander & $\begin{array}{l}\text { Baft, Zarand and } \\
\text { Kerman }\end{array}$ \\
\hline $\begin{array}{l}\text { Aonidiella orientalis } \\
\text { Newstead, } 1894\end{array}$ & Aspidiotinae & Aspidiotini & Citrus sinensis & Jiroft and Kahnooj \\
\hline $\begin{array}{l}\text { Diaspidiotus armenicus } \\
\text { Borchsenius, } 1935\end{array}$ & Aspidiotinae & Aspidiotini & Salix sp. & Baft and Bardsir \\
\hline $\begin{array}{l}\text { Diaspidiotus gigas Thiem } \\
\text { and Gerneck, } 1934\end{array}$ & Aspidiotinae & Aspidiotini & Populus sp. & Baft \\
\hline $\begin{array}{l}\text { Lepidosaphes conchiformis } \\
\text { Gmelin, } 1790\end{array}$ & Diaspidinae & Diaspidini & Juglans regia & $\begin{array}{l}\text { Baft, Bardsir, } \\
\text { Rafsanjan and } \\
\text { Zarand }\end{array}$ \\
\hline $\begin{array}{l}\text { Lepidosaphes malicola } \\
\text { Borchsenius, } 1947\end{array}$ & Diaspidinae & Diaspidini & Fraxinus excelsior & $\begin{array}{c}\text { Baft, Bam, Bardsir, } \\
\text { Rabor, Rayen and } \\
\text { Rafsanjan }\end{array}$ \\
\hline $\begin{array}{c}\text { Lepidosaphes pistaciae } \\
\text { Archangelskaya, } 1930\end{array}$ & Diaspidinae & Diaspidini & Pistacia vera & $\begin{array}{l}\text { Anar, Baft, Bam, } \\
\text { Bardsir, } \\
\text { Kebootarkhan, } \\
\text { Kerman, Rafsanjan, } \\
\text { Shahr-e-babak, } \\
\text { Sirjan and Zarand }\end{array}$ \\
\hline $\begin{array}{c}\text { Leucaspis pusilla Löw, } \\
1883\end{array}$ & Aspidiotinae & Leucaspidini & Pinus sp. & Baft and Kerman \\
\hline $\begin{array}{c}\text { Lopholeucaspis japonica } \\
\text { Cockerell, } 1897\end{array}$ & Diaspidinae & Leucaspidini & Pyracantha sp. & Kerman \\
\hline $\begin{array}{c}\text { Mercetaspis halli Green, } \\
1923\end{array}$ & Diaspidinae & Diaspidini & Amygdalus communis & $\begin{array}{l}\text { Baft, Kerman and } \\
\text { Shahdad }\end{array}$ \\
\hline $\begin{array}{l}\text { Melanaspis inopinata } \\
\text { Leonardi, } 1913\end{array}$ & Aspidiotinae & Aspidiotini & Acacia $\mathrm{sp}$ & $\begin{array}{c}\text { Anar, Baft, Bardsir, } \\
\text { Kerman, Rafsanjan, } \\
\text { Shahr-e-babak, } \\
\text { Sirjan and Zarand }\end{array}$ \\
\hline $\begin{array}{c}\text { Melanaspis louristana } \\
\text { Balachowsky and Kaussari, } \\
1953\end{array}$ & Aspidiotinae & Aspidiotini & Acer monspessulanum & Rabor \\
\hline Parlatoria blanchardi & Aspidiotinae & Parlatoriini & Phoenix dactylifera & Bam and Jiroft \\
\hline
\end{tabular}




\begin{tabular}{|c|c|c|c|c|}
\hline $\begin{array}{l}\text { Parlatoria crypta } \\
\text { McKenzie, } 1943\end{array}$ & Aspidiotinae & Parlatoriini & Fraxinus excelsior & $\begin{array}{l}\text { Baft, Kerman and } \\
\text { Zarand }\end{array}$ \\
\hline $\begin{array}{c}\text { Parlatoria oleae Colvée, } \\
1880\end{array}$ & Aspidiotinae & Parlatoriini & Malus pumila & Baft and Rabor \\
\hline $\begin{array}{c}\text { Salicola archangelskyae } \\
\text { Lindinger, } 1929\end{array}$ & Aspidiotinae & Leucaspidini & Fraxinus excelsior & $\begin{array}{l}\text { Bardsir, Kerman } \\
\text { and Sirjan }\end{array}$ \\
\hline $\begin{array}{c}\text { Salicola davatchii } \\
\text { Balachowsky and Kaussari, } \\
1951\end{array}$ & Aspidiotinae & Leucaspidini & Ficus carica & Anar \\
\hline $\begin{array}{c}\text { Salicicola kermanensis } \\
\text { Lindinger,1905 }\end{array}$ & Aspidiotinae & Leucaspidini & Salix sp. & Bardsir and Rayen \\
\hline $\begin{array}{l}\text { Targionia porifera } \\
\text { Borchsenius, } 1949\end{array}$ & Aspidiotinae & Aspidiotini & $\begin{array}{l}\text { Zygophyllum } \\
\text { eurypeterum }\end{array}$ & Rabor \\
\hline
\end{tabular}

\section{Diaspidiotus gigas Thiem and Gerneck 1934}

Synonyms. Aspidiotus populi Glaser 1877; Aspidiotus (Euraspidiotus) gigas Thiem and Gerneck 1934; Aspidiotus multiglandulatus Borchsenius 1935; Aspidiotus gigas Ferris 1941; Quadraspidiotus gigas Balachowsky 1948; Diaspidiotus gigas Borchsenius 1949; Quadraspidiotus gigans Bachmann 1956; Diaspidiotus gigas Danzig 1980; Aspidiotus multigrandulatus Chou 1985.

Common name: poplar scale.

Material examined, Kerman. Baft, N: 28 49' 21.65", E: 56 18' 58.63", 2003 m a.s.1., trunk of Populus sp., leg. M. Rouhani, 3.V.2013, leg. no: SMR - 132; Baft, N: $29^{\circ} 18^{\prime}$ 11.86", E: 56 43' 08.06", 2960 m a.s.l., on trunk of Populus sp., leg. M. Rouhani, 4.V.2013, leg. no: SMR - 133; Baft, N: 29 15' 35.13", E: 56 42' 24.77", 2391 m a.s.1., on trunk of Populus sp., leg. M. Rouhani, 4.V.2013, leg. no: SMR - 134.

Distribution. D. gigas has recorded from Azerbaijan, Georgia, Kazakhstan, Caucasus, Dagestan, Turkey and some parts of Europe and other zoogeographical regions ${ }^{2}$. This is the new country illustrate for Iran (Kerman).

Habitate. Specimen of D. gigas is found on the bark of the branches and trunk; small populations are difficult to detect. The bark can be visually inspected for scales and feeding marks.

Field characters. Scale cover of adult female moderately convex and circular, gray, about $2 \mathrm{~mm}$ in diameter, usually dark brown in central area and greyish to cream toward edges. Scale cover with three concentric circles; ventral scale well developed and dark brown, but the greater part of it remains attached to the plant and appears greyish to cream colored.

\section{Diagnosis of slide-mounted adult female of $D$. gigas (Figure 1)}

Female body pyriform, length $0.9-1.6$ (1.2) mm, length $0.8-1.4$ (1.1) mm. Antennae normally each with 1 long lateral seta. Perispiracular pores absent. Pygidium wide and obtuse, with 3 pairs of lobes (L1, L2, L3), rarely with a weakly developed fourth lobe. Lobes parallel, asymmetrical and crescent-shaped, separated from each other by a space $0.1-0.3$ (0.2) times width of median lobe. Median lobe (L1) only slightly larger than second lobes, each median lobe with 1 lateral notch, without any basal sclerotization. Second lobes (L2) each simple, about one-half size of a median lobe, more acute medially 
than L1, each L2 with rounded apex and 0-2 (1) lateral notches. Third lobes (L3) simple, similar shape to L2 but smaller and without notches. Fourth lobes (L4) absent. Space between median lobes containing 2 slender simple plates, each about 0.5 times as long as a median lobe; $2^{\text {nd }}$ and $3^{\text {rd }}$ interlobular spaces containing plates that are usually bifurcate or fringed; plate formula commonly 2-2-0, rarely 2-3-0. Perivulvar pores present, arranged in 5 groups, formula: median group 5-11 (7), submedial groups 11-19 (13) each, and lateral groups 7-17 (12) each; median group is situated anterior to level of anal opening. Dorsal macroducts present, 3 macroducts between L1 and L2, 2 macroducts between L2 and L3. Ventral microducts very long and slender, numerous, present in submarginal area of pygidium and submedial areas of prepygidial segments.

Host-plants. Salicaceae: Populus sp. The species seems to be oligophagous, with a narrow range of host-plants in the Salicaceae such as Salix sp.; S. babylonica and Populus sp.

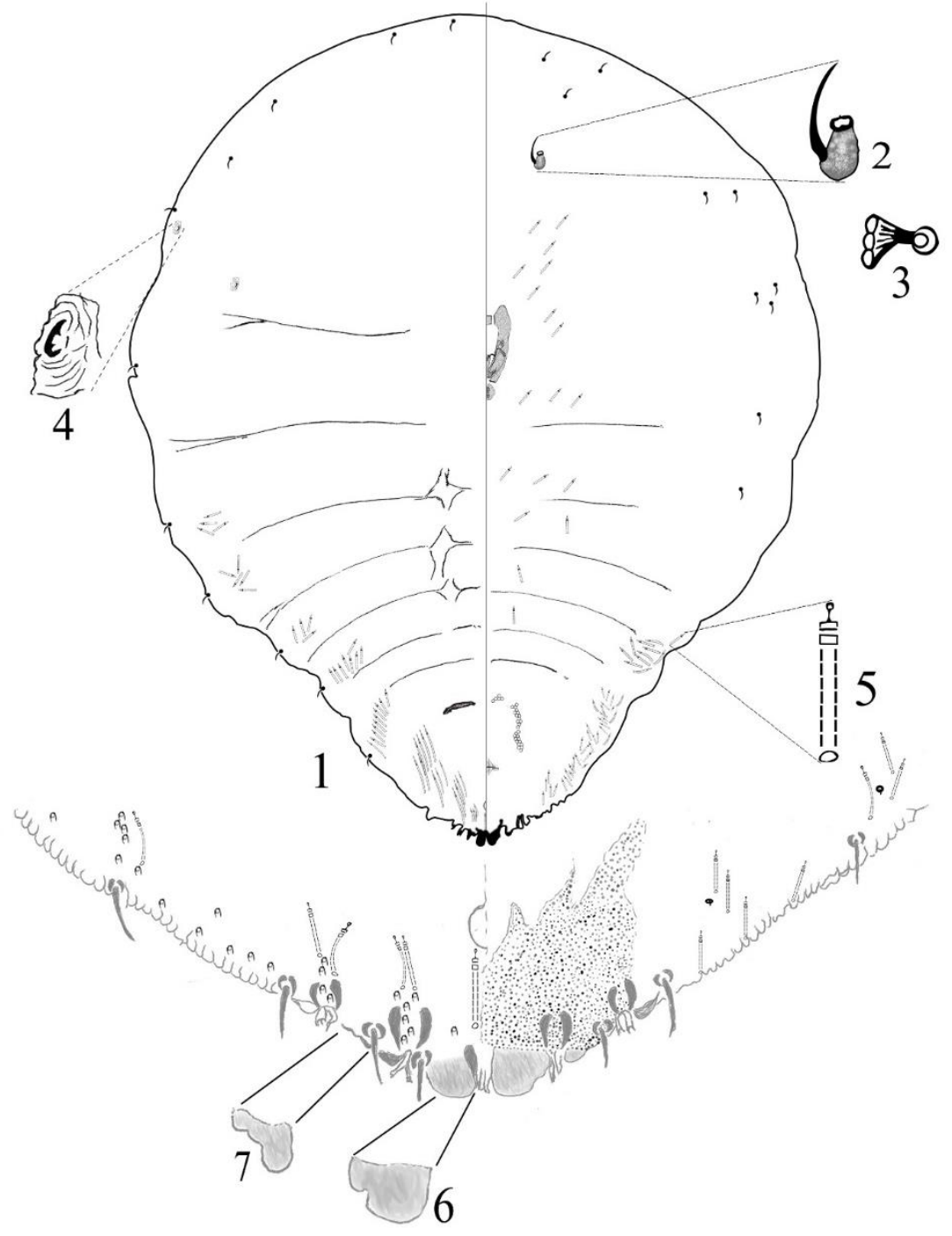

Figure 1- Diaspidiotus gigas Thiem and Gerneck 1934: Adult female, illustration by M. Rouhani. Details: (1) habitus (2) antenna (3) anterior spiracle (4) dorsal eyespot (5) dorsal macroduct (6) median lobe (7) detail of second lobe. 


\section{Aspidiotus nerii Bouché 1833}

Synonyms. There are 139 synonyms of Aspidiotus nerii ${ }^{2}$, including Aspidiotus hederae Vallot 1829; Aspidiotus genistae Westwood 1840; Diaspis bouchei Targioni Tozzetti 1867; Chermes aloes Boisduval 1867; Chermes ericae Boisduval 1867; Chermes cycadicola Boisduval 1867; Chermes nerii Boisduval 1868; Aspidiotus affinis Targioni Tozzetti 1868; Aspidiotus bouchei Targioni Tozzetti 1868; Aspidiotus caldesii Targioni Tozzetti 1868; Aspidiotus denticulatus Targioni Tozzetti 1868; Aspidiotus villosus Targioni Tozzetti 1868.

Common name: Oleander scale.

Material examined, Kerman. Zarand, N: 30 46' 10.92", E: 56 38' 01.63", 2677 m a.s.1., on branches of Phoenix sp., leg. M. Rouhani, 6.VI.2014, leg. no: SMR - 53; Zarand, N: $30^{\circ} 48^{\prime} 31.99^{\prime \prime}$, E: 56 $33^{\prime} 48.36^{\prime}, 1656$ m a.s.l., on branches of Nerium oleander, leg. M. Rouhani, 12.V.2013, leg. no: SMR - 57; N: 30 16' 25.10", E: 5709' 32.75", 1796 m a.s.l., on branches, trunk and leaves of Phoenix sp., leg. M. Rouhani, 14.VII.2016, leg. no: SMR - 54; N: 30 15' 46.45", E: 57 05' 13.09", $1768 \mathrm{~m}$ a.s.1., on branches trunk and leaves of Nerium oleander, leg. M. Rouhani, 12.V.2013, leg. no: SMR - 55; Rayen, N: $29^{\circ} 35^{\prime} 29.12^{\prime \prime}$, E: 57 $26^{\prime} 26.96 ", 2203$ m a.s.l., on branches and trunk of Phoenix sp., leg. M. Rouhani, 1.VII.2015, leg. no: SMR - 56.

Distribution. A. nerii is widely distributed in almost all zoogeographical regions; it has recorded so far from 73 countries including, Asia, Russia, Europe, United States, Australia and Africa ${ }^{2}$. New province record for Kerman.

Habitate. A. nerii can be found on almost all woody plants (twigs and leaves). The scales are located on the bark of branches and leaf surfaces, and small populations are difficult to detect. Bark and leaves can be visually inspected for scales, and feeding marks. Eggs are hidden beneath scale covers, not visible. Some hosts for A. nerii include: Achariaceae: Melicytus ramiflorus, Actinidia chinensis; Anacardiaceae: Pistacia vera; Apocynaceae: Nerium oleander and Hemidesmus sp (Sarsapaeilla); Araliaceae: Hedera canariensis; Arecaceae: Phoenix sp. and Washingtonia spp.; Asparagaceae: Asparag officinalis and A. plumosus; Oleaceae: Olea europaea; Orchidaceae: Maxillaria longipetala; Pinaceae: Pinus sp.; Tamaricaceae: Tamarix sp., from Iran (Elborz (Karaj), Esfahan, Markazi, Golestan, Gilan (Rasht), Thehran, Fars and Mazandaran) ${ }^{1,23,24}$.

Field characters. Scale cover of adult female circular to subcircular, slightly convex and pale cream colored, about 1.2 - 1.8 (1.5) mm long; usually dark brown in central area, white to cream toward edges.

\section{Diagnosis of slide-mounted adult female of $A$. nerri (Figure 2)}

Body of adult female pyriform, length $0.85-1.2$ (1) $\mathrm{mm}$ and breadth $0.6-1$ (0.8) $\mathrm{mm}$. Antennae small, each with 1 fleshy seta. Spiracles strongly sclerotised, perispiracular pores absent. Pygidium slightly obtuse, with 3 pairs of lobes (L1, L2, L3). Median lobes (L1) large, parallel, symmetrical, each with 2 notches on outer side. L2 smaller than L1, asymmetrical, each lobe with 1 or 2 recognizable notches. L3 spiniform or conical, smaller than second lobes. Median and lateral plates well developed, longer than lobes, fringed; 4-8 plates present lateral to each third lobe. Plate formula commonly 2-2-5, rarely 2-2-6 or 2-2-8. Anal opening oval. Perivulvar pores present, arranged in 4 or 5 groups, formula: median group 5-13, submedial groups 5-15 each, and lateral groups 0 or 1 each; 
submedial group is situated anterior to level of anal opening. Ventral microducts few, mostly submarginal. Dorsal ducts short.

Host-plants. Apocynaceae: Nerium oleander; Arecaceae: Phoenix sp. It is a highly polyphagous pest, with a wide range of host-plants e.g. on 325 plant species belonging to 120 families $^{2}$. The scale has been recorded as a pest of palm, oleander and citrus ${ }^{1,3,25}$.
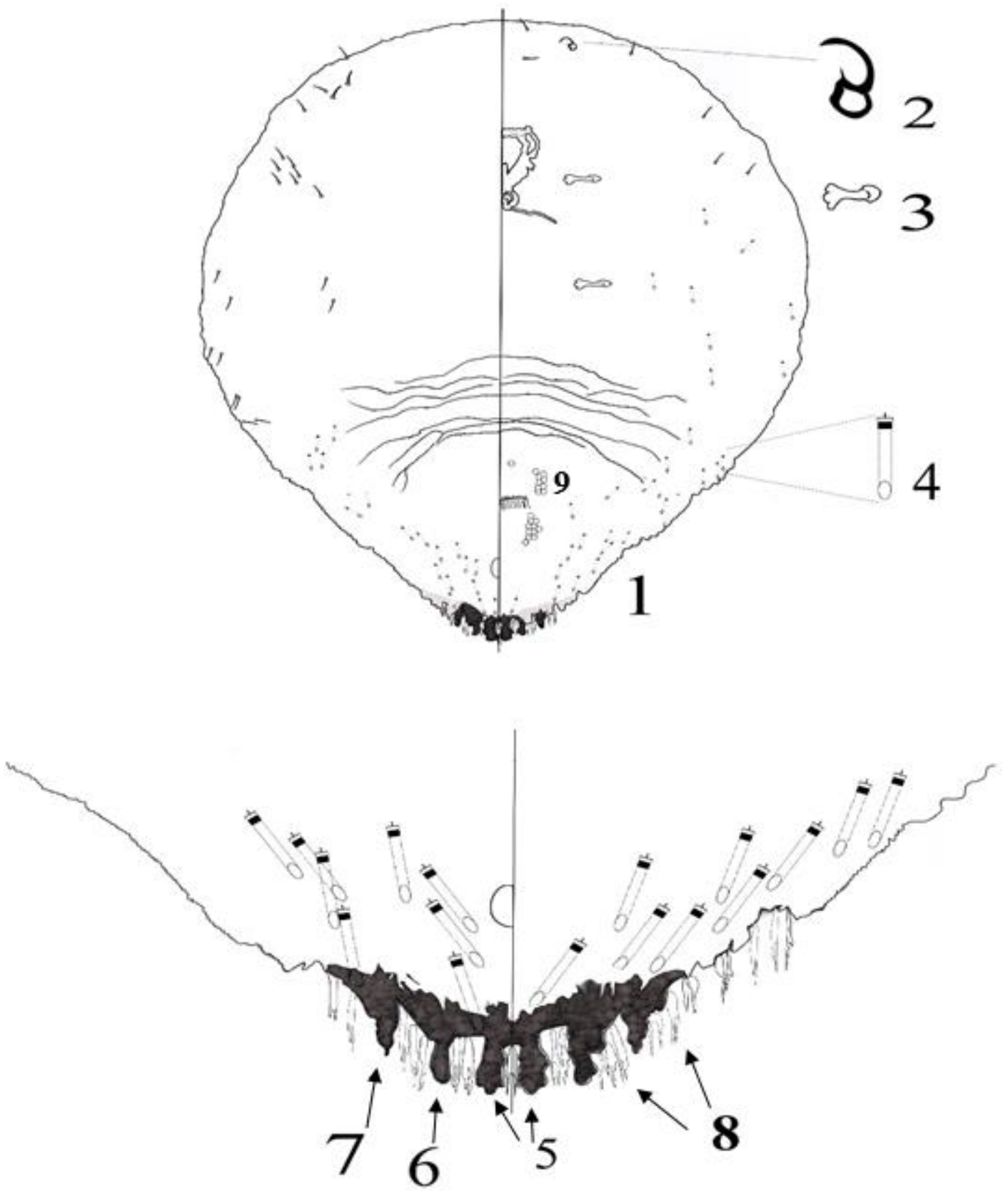

Figure 2 - Aspidiotus nerii Bouché, 1833: Adult female, illustration by M. Rouhani. (1) habitus. Details: (2) antenna, (3) anterior spiracle, (4) dorsal macroduct, (5) median lobes, (6) second lobe, (7) third lobe, (8) plates, (9) Perivulvar pores. 


\section{Diaspidiotus armenicus Borchsenius, 1935}

Synonyms. Aspidiotus armenicus Borchsenius 1935; Diaspidiotus armenicus Borchsenius 1949; Quadraspidiotus armeniacus Borchsenius 1949.

Material examined, Kerman. Baft, N: 29 13' 42.60", E: 56 36' 34.14", 2253 m a.s.l., on trunk and branches of Salix sp., leg. M. Rouhani, 3.V.2013, leg. no: SMR - 11; Baft, N: 29 $9^{\circ} 14^{\prime} 04.81^{\prime \prime}$, E: 56 37' 14.33", 2268 m a.s.l., on branches of Salix sp., leg. M. Rouhani, 7.V.2013 leg. no: SMR - 13; N: 30 17' 27.91", E: 57 05' 27.91", 1764 m a.s.1., trunk and branches of Salix babylonica, leg. M. Rouhani, 1.VII.2015, leg. no: SMR - 12; Bardsir, N: $29^{\circ}$ 56' 36.66", E: 56 34' 27.39", 2322 m a.s.l., on branches of Salix sp., leg. M. Rouhani, 30.VI.2015, leg. no: SMR - 14.

Distribution. D. armenicus has been recorded from Iran, Armania, Pakistan and Turkey ${ }^{2}$. Detection. $D$. armenicus can be found on the bark of the trunk and branches, and small populations are difficult to detect. The bark can be visually inspected for scales and feeding marks.

Field characters. Scale cover of adult female flat and circular, about $2.5 \mathrm{~mm}$ in diameter, usually dark gray with golden (or yellowish) exuviae in central area; scale cover with irregular edges.

\section{Diagnosis of slide-mounted adult female (Figure 3)}

Body of adult female pyriform, length $1.15-1.5$ (1.3) $\mathrm{mm}$ and length $1-1.3$ (1) $\mathrm{mm}$. Antennae small and inconspicuous, each with 1 seta. Spiracles clearly defined, perispiracular pores absent. Pygidium wide and obtuse, with 3 pairs of lobes (L1, L2, L3); L4 absent. Median lobes (L1) large, each with a notch on either side and a setae on that, with a conspicuous basal sclerosis. Plates absent from space between median lobes. Second lobe (L2) smaller than L1, each with 1 notche on outer side with 2 setae on inner side; third lobes (L3) reduced and weakly sclerotised, barely recognizable, with 2 setae. Anal opening circular. Perivulvar pores present in 5 groups, formula: median group 2-7 (5), submedial groups 10-15 (13) each, and lateral groups 6-10 (8). Dorsal macroducts concentrated between lobes and lateral to L3, each duct short and narrow, macroducts increasingly numerous anterior to pygidium. Ventral microducts few in number, threadlike and scattered.

Host-plants. Salicaceae: Salix sp. and Populus alba. 


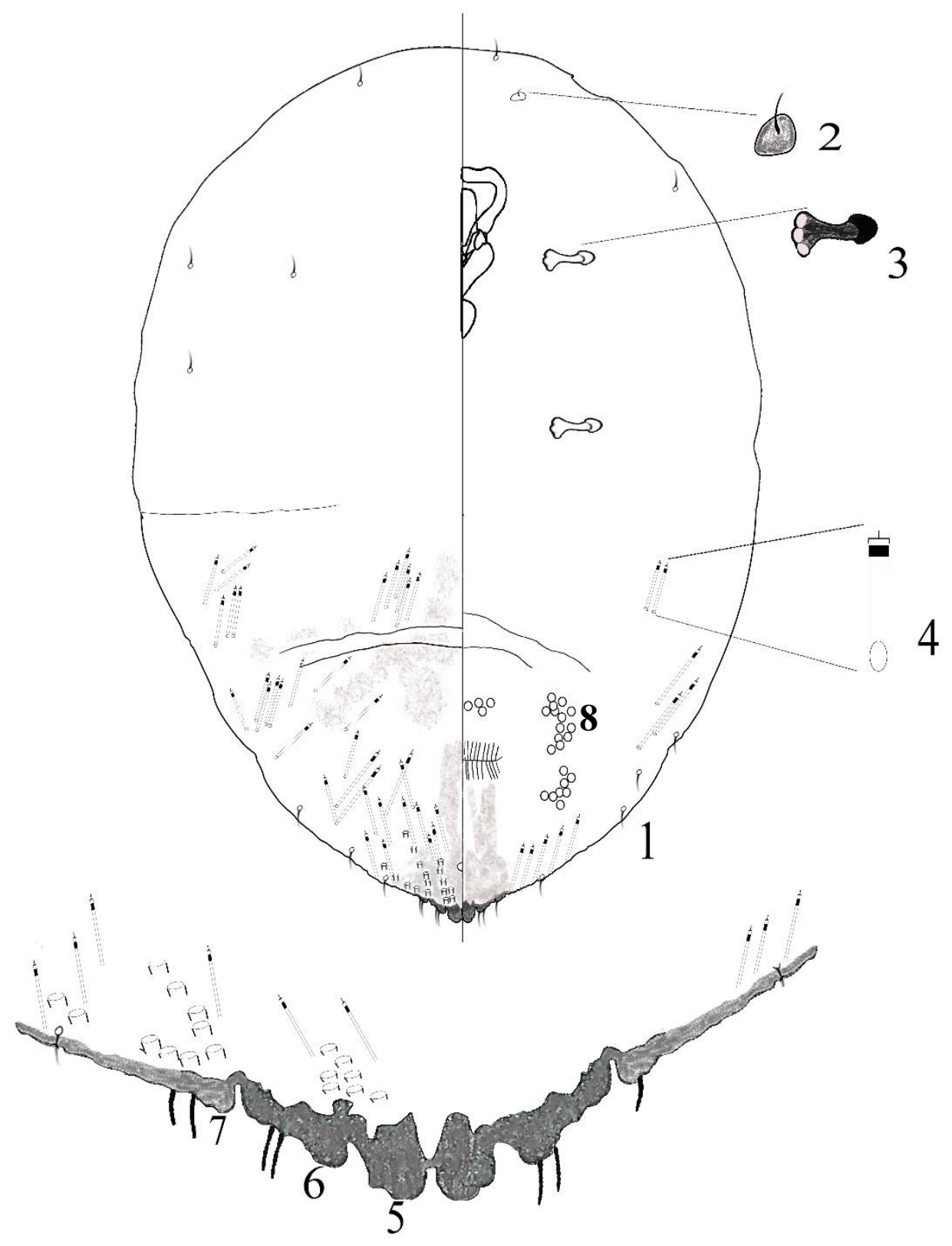

Figure 3 - Diaspidiotus armenicus Borchsenius 1935: Adult female, illustration by M. Rouhani. (1) habitus. Details: (2) antenna, (3) anterior spiracle, (4) dorsal duct, (5) median lobes, (6) second lobe, (7) third lobe, (8) Perivulvar pores. 


\section{Leucaspis pusilla Löw, 1883}

Synonyms. Leucaspis leonardi Coleman 1903; Leucaspis (Euleucaspis) pusilla Lindinger 1906; Actenaspis pusilla Leonardi 1906; Leucaspis leonardii Lindinger 1907; Leucaspis perezii Green 1915.

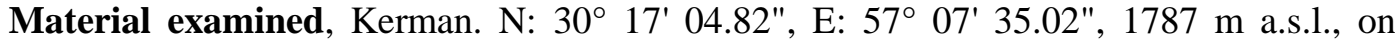
branches of Pinus sp., leg. M. Rouhani, 12.V.2013, leg. no: SMR - 16; N: 30 16' 49.83", E: $57^{\circ} 01^{\prime} 24^{\prime \prime}, 1757 \mathrm{~m}$ a.s.1., on branches and trunk of Pinus sp., leg. M. Rouhani, 12.VI.2016, leg. no: SMR - 17; Bardsir N: 29 56' 05.57", E: 56 34' 38.89", 2045 m a.s.l., on branches and trunk of Pinus sp., leg. M. Rouhani30.VI.2015, leg. no: SMR - 18; Baft N: 29 13' 56.12", E: 56 37' 30.68", 2307 m a.s.l., on branches of Pinus sp., leg. M. Rouhani, 30.VIII.2016, leg. no: SMR - 19.

Distribution. L. pusilla has been recorded from Iran, Iraq, Israel, Egypt, Georgia, Syria, Turkey and some parts of Europe and other zoogeographical regions ${ }^{2}$.

Detection. L. pusilla is located on the bark of trunk and branches of Pinaceae (not on the needles), and small populations are difficult to detect. Bark can be visually inspected for scales and feeding marks.

Field characters. Adult female pupillarial: scale cover elongate, narrow, lanceolate, slightly wider posteriorly and with only one apical exuviae, white in color. About $2.5 \mathrm{~mm}$ long and $1.5-1.9(1.7) \mathrm{mm}$ wide.

Diagnosis of slide-mounted second instar and adult female of $L$. pusilla (Figures 4 and 5)

Body of adult female elongate, almost oval, length $1.3-1.8$ (1.6) $\mathrm{mm}$ and length $0.9-1.3$ (1.2) $\mathrm{mm}$. Antenna with 3 long, fleshy setae. Perispiracular pores present, each anterior spiracle associated with 3 or 4 pores. Posterior perispiracular pores absent. Pygidium short, narrow, semi-circular, with 3 pairs of lobes (L1, L2, L3). Plates long, well developed and fringed, mostly narrowing apically, some long and serrate apically, numbering $10-17$ on each side of pygidium. Anal opening circular with a thick rim, situated at center of pygidium. Perivulvar pores in 5 groups, formula: median group 8-11, submedial groups 8-15 each, and lateral groups 3-5 each, mostly pores are connected together. Dorsal macroducts few ( 3 or 4 on each side). Second instar with 3 pairs of lobs (L1, L2, L3); L3 pectinated. Lateral plates short, enlarged, strongly serrated apically, not as wide as lobs. Marginal ducts developed, with ring-like oral scleroses.

Host-plants. Pinaceae: Pinus sp. The species seems to be monophagous on Pinaceae. 


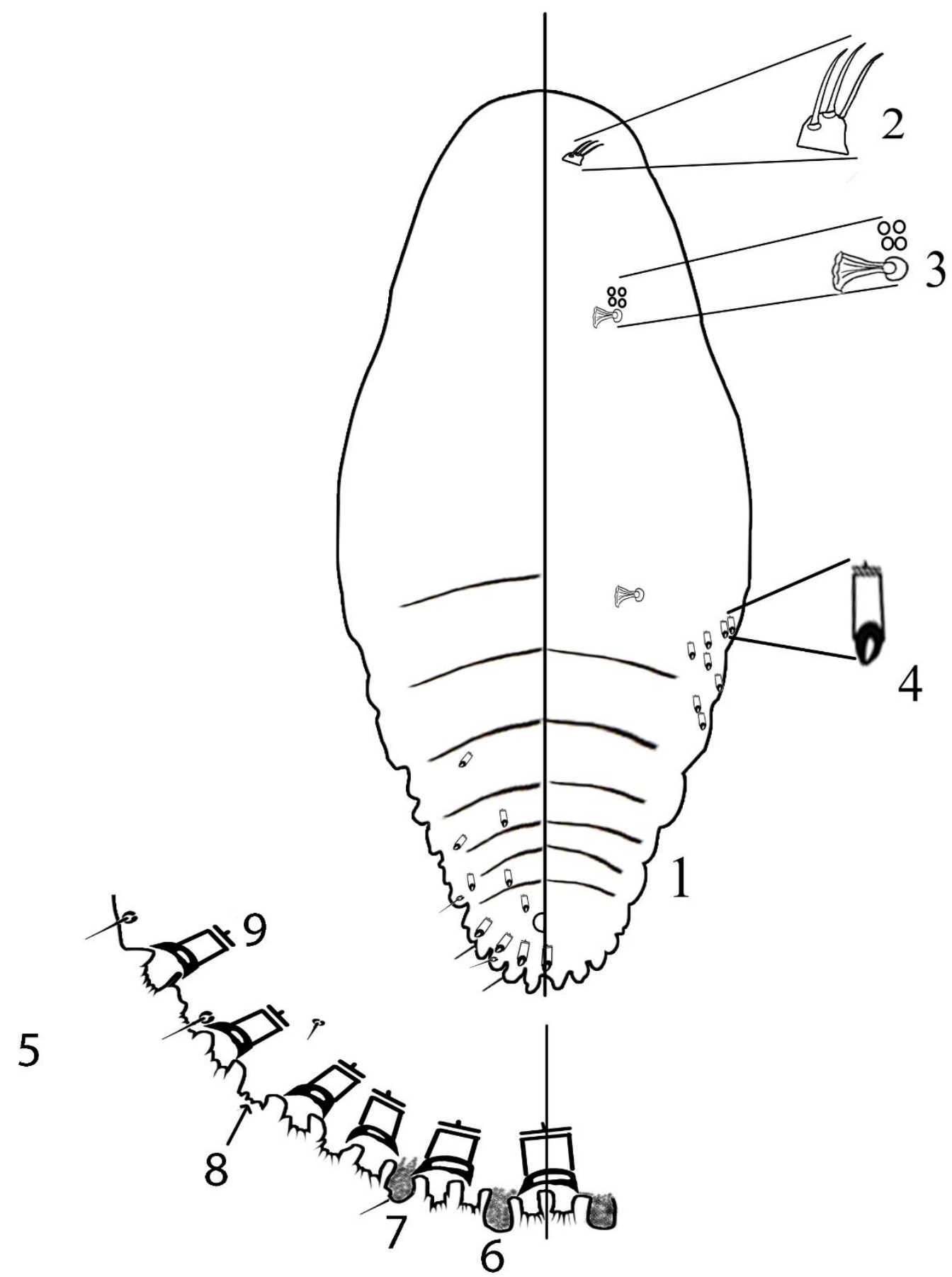

Figure 4 - Leucaspis pusilla Löw 1883: Second instar female, illustration by M. Rouhani. (1) habitus. Details: (2) antenna, (3) anterior spiracle and perispiracular pores, (4) dorsal duct, (5) dorsal detailes of pygidial margin, (6) median lobe, (7) second lobe, (8) third lobe, (9) lateral macroduct. 

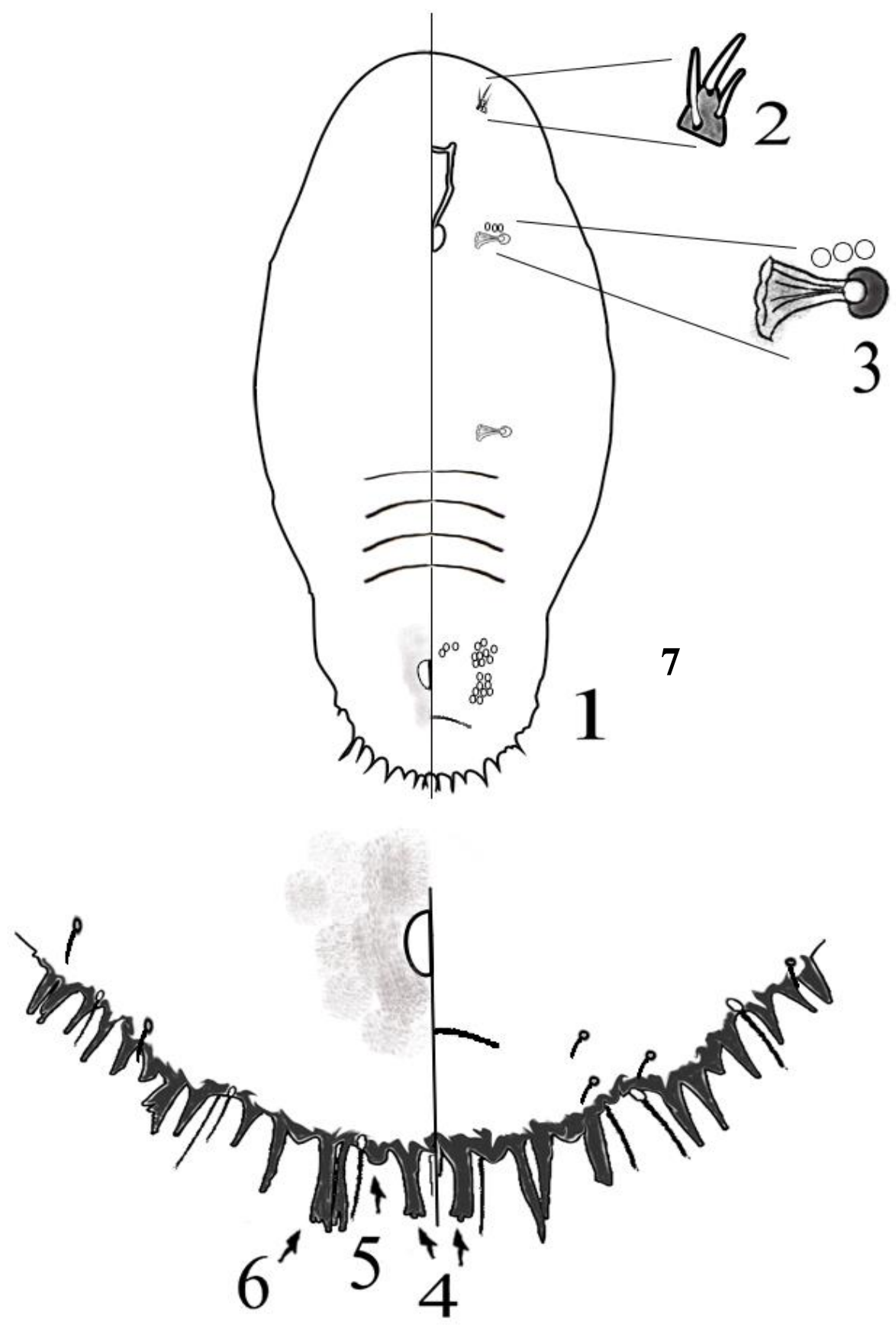

Figure 5 - Leucaspis pusilla Löw 1883: Adult female, illustration by M. Rouhani. (1) habitus. Details: (2) antenna, (3) anterior spiracle and perispiracular pores, (4) median lobes, (5) second lobe, (6) plates, (7) Perivulvar pores. 
Melanaspis louristana Balachowsky and Kaussari, 1953

Synonyms. Melanaspis louristanus Balachowsky and Kaussari 1953; Melanaspis lauristanus (Balachowsky and Kaussari) Kaussari 1955; Melanaspis louristanus (Balachowsky and Kaussari) Borchsenius 1966; Melanaspis louristana (Balachowsky and Kaussari) Pellizzari and Williams 2013.

Material examined, Kerman. Rabor N: 29 16' 41.76", E: 57 10' 52.50", 2519 m a.s.1., on branches, trunk and leaves of Acer monspessulanum, leg. M. Rouhani, 6.V.2013 leg. no: SMR - 42; Rabor N: 29 15' 48.78", E: 57 13' 45.86", 2716 m a.s.l., on branches and trunk of Prunus amygdalus var amara, leg. M. Rouhani, 8.V.2015 leg. no: SMR - 43.

Distribution. M. louristana has been recorded from Iran (Fars: Kazeron) ${ }^{22}$ and Israel ${ }^{2}$.

Detection. M. louristana feeds on the bark of trunk and branches, and on leaves; small populations are difficult to detect. Bark can be visually inspected for the scales and feeding marks.

Field characters. Scale cover of adult female circular to sub-circular, slightly convex, about 1.9 - 2.7 (2.3) $\mathrm{mm}$ long and 1.4 - 1.9 (1.6) $\mathrm{mm}$ wide, dark grey; first exuviae central, black to dark brown. A ventral thin wax layer remains attached to the host-plant.

\section{Diagnosis of slide-mounted adult female of M. louristana (Figure 6)}

Body of adult female circular, length $0.9-1.6$ (1.3) $\mathrm{mm}$ and length $0.9-1.3$ (1) $\mathrm{mm}$. Antennal tubercle conical, with 1 short, fleshy seta. Perispiracular pores absent. Pygidium with 4 pairs of lobes (L1, L2, L3, L4). Median lobes (L1) each barely larger than other lobes, symmetrical, with a basal sclerosis, situated close together without a clear space or plates between them; second lobe (L2) smaller than L1, also without any lateral notches like L1, without basal sclerotization; third lobe (L3) larger than L2 but slightly smaller than L1, similar shape to L2 but slightly more square with irregular corners; fourth lobe (L4) the smallest of the lobes, narrower and variable in shape, with a notch on outer side. Plates absent. Paraphyses clearly visible at inner basal corners of lobes, fusiform; also 6 secondary paraphyses present between lobes: 1 (rarely 2) between L1 and L2, 2 between L2 and L3, 3 between L3 and L4. Anal opening triangular and thick-rimmed, situated below level of perivulvar pores. Perivulvar pores present in 5 groups, formula: median group 2 or 3, submedial groups 7-11 each, and lateral groups 5-9 each; submedial group situated above anal opening. Dorsal ducts numerous, situated in long furrows, as follows: 7 or 8 ducts in furrow on segment VII, over 30 ducts in furrow on segment VI and fewer than 30 ducts in furrow on segment V. Microducts few, present on segments IV - V.

Host-plants. Fagaceae: Quercus sp., Rosaceae: Prunus amygdalus and Sapindaceae: Acer monspessulanum. We collected it from members of the families Rosasae, Sapindaceae and Fagaceae, which are probably preferred hosts. Prunus amygdalus var amara (bitter

almond, Rosaceae) and Acer monspessulanum represent new host records. The scale also infests the leaves of Acer monspessulanum. 


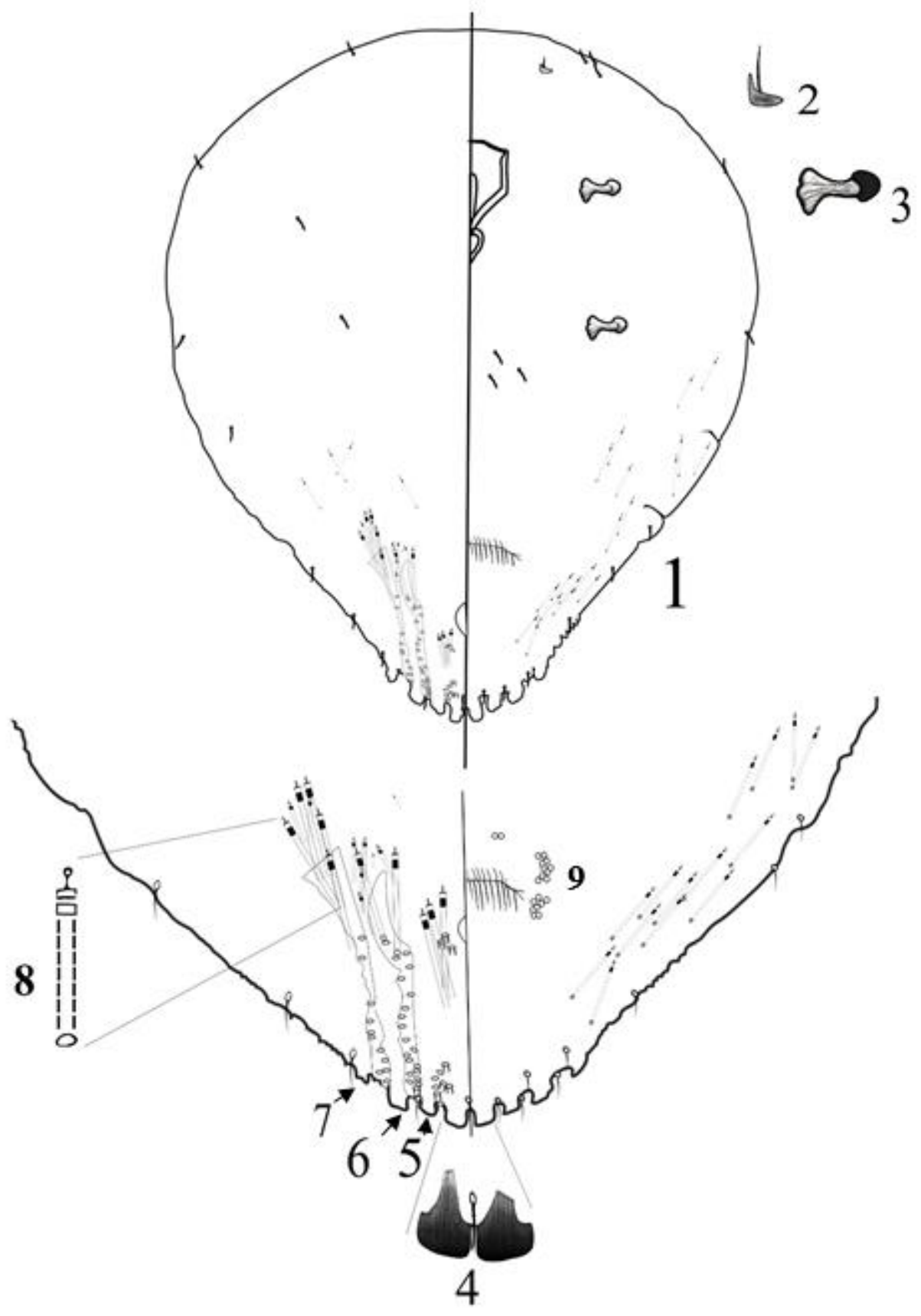

Figure 6 - Melanaspis louristana Balachowsky and Kaussari 1953: Adult female, illustration by M. Rouhani. (1) habitus. Details: (2) antenna, (3) anterior spiracle, (4) median lobes (5) second lobes, (6) third lobe, (7) fourth lobe (8) dorsal duct, (9) Perivulvar pores. 


\section{DISCUSSION}

Iran has a long experience in planting wide varieties of pistachio nut and Rosacae fruit. The nut, Pistasia vera, and the fruit such as Malus spp. and Prunus spp have gained popularity with peoples all over the world.

The diaspidids have been serious pests of nut and fruit trees for long time. The family Diaspididae include the largest number of species injuring to nuts and fruit crops. The literature study shows that, among 20 recorded species in the study area of which 12 species associated with Rosaceae (60\%); of these, 8 species are recorded both on Rosaceae and Anacardiaceae (66\%), the diaspidids can cause serious damage to nut (Anacardiaceae) and fruit trees (Rosaceae). There are many potential causes of scale insect outbreaks, including changes in climate, host resource availability and pesticides.

Nut and fruit growers must make following effective scale insect pest management: Preventive practices, properly identifying key pest scale insects (Lepidosaphes pistaciae), selecting and using preventive pest management practices, monitoring the current status of scale insect populations, determining the pest's economic loss potential, selecting the proper scale pest control option and evaluating the effectiveness of previously used control options.

\section{ACKNOWLEDGMENTS}

We wish to express our special thanks to Dr. Gillian Watson. The review, comments and suggestions were very helpful.

\section{REFERENCES}

1- Moghaddam M. An annotated checklist of the scale insects of Iran (Hemiptera, Sternorrhyncha, Coccoidea) with new records and distribution data. ZooKeys. 2013; 334: 1-92.

2- García Morales M, Denno BD, Miller DR, Miller GL, Ben-Dov Y, Hardy NB. ScaleNet: a literature-based model of scale insect biology and systematics. Database. 2016. (accessed on 15 Dec. 2016).

3- Lehr PA. Keys to Insects of the far east of the USSR. Vol. II. Homoptera and Hemiptera. Nauka publishing house, Leningrad. 1988.

4- Watson G. Arthropods of economic importance: Diaspididae of the world. An illustrated identification guide and information source. CD-ROM. Expert Center for Taxonomic Identification (ETI), University of Amsterdam, The Netherlands. 2002a; 40-48.

5- Watson G. A pictorial key to important Diaspididae (Hemiptera: Coccoidea) of the world. Boll Zoo Agra Bach. 2002b; 33: 175-178.

6- Ben-Dov Y, German V, Miller DR, Gibson GA. ScaleNet, scales in a country query results. Intercept Limited; 2010.

7- Archangelskaya A. The Coccidae of Middle Asia. Izdatelstvo Komiteta Nauk UZSSR, Tashkent; 1937.

8- Afchar D. Insectes nuisibles aux arbres fruitieres en Iran. Ministry of Agriculture, Iran; 1937.

9- Borchsenius N. A new genus and new species of hard scales from Iran (Homoptera, Coccoidea). Entomologicheskoe Obozrenye. 1952; 32: 261-263.

10- Balachowsky A. Sur un nouvel Aspidiotini (Coccoidea) de l'Iran. Revue de Pathologie Végétale et d'Entomologie Agricole de France. 1959; 38: 211-212.

11- Balachowsky A. Une Espece Nouvelle de Fiorina (Coccidea: Diaspidini) Vivant Sur PalmierDattier Dans les Oasis du Sud Liran. In: Annales de la Societe Entomologique de France. Soc Entomologique de France. 1967; p. 771. 
12- Hodgson CJ, Henderson RC. Coccidae (Insecta: Hemiptera: Coccoidea). Fauna N Z. 2000; 41: $1-264$.

13- Kaussari M. The second list of scales from Iran. Ministry of Agriculture, Iran. Entomologie et Phytopathologie Appliquées. 1957; 16-17: 1-3.

14- Kaussari M. Monographie des Coccoidea de l'Iran. Ministry of Agriculture, Iran. Conseil Supérieur de Recherches Agronomiques Bulletin. 1970.

15- Seghatoleslami H. List of scale insects (Fam. Diaspididae) of Iran. J Entomol Soc Ir. 1977; 4: 5-19.

16- Torabi M, Vahedi H, Hodgson C. Preliminary survey of the scale insects fauna in Kermanshah, western Iran. Entomol Hell. 2010; 19: 153-162.

17- Rozdar E, Vahedi H, Mossadegh M, Samih M. The scale insects (Hem.: Coccoidea) of Behbahan county and their morphological characters. Plant Prot. 2013; 36: 41-68.

18- Hosseininaveh F, Nozari J, Kaydan MB, Hosseininaveh V. Molecular and morphological identification of pistachio armoured scale insects (Hemiptera: Diaspididae), with description of a new species. Zootaxa. 2016; 4200: 523-543.

19- Stoetzel M. Scale-cover formation in the Diaspididae (Homoptera: Coccoidea). Proc Entomol Soc Wash. 1976; 78: 323-332.

20- Danzig E. Fauna of Russia and neighbouring countries. Rhynchota, Volume X: suborder scale insects (Coccinea): families Phoenicococcidae and Diaspididae. Nauka, S.-Peterburgskoe Otdelenie. 1993.

21- Gill R. The scale insects of California: Part 3, The armored scales (Homoptera: Diaspididae). California Department of Food and Agriculture, Sacramento, CA. 1997.

22- Moghaddam M. Fauna of armored scales (Homoptera: Diaspididae) of Fars province. Shiraz university. 1998.

23- Bodenheimer F. Note on the Coccoidea of Iran, with description of new species. Bulletin de la Société Fouad ler d'Entomologie. 1944; 28: 85-100.

24- Modarres-Awal M. List of agricultural pests and their natural enemies in Iran. Ferdowsi University of Mashhad Publication. 1994.

25- Erler F, Tunc I. A survey (1992-1996) of natural enemies of Diaspididae species in Antalya, Turkey. Phytoparasitica. 2001; 29: 299-305. 